\title{
EVALUATION OF PAP SMEAR SCREENING HISTORY IN PATIENTS WITH CERVICAL CANCER IN ISFAHAN PROVINCE DURING 2014-2016
}

\author{
Mahmoud Mosayebi, Negah TavakoliFard \\ Community Medicine Department, School of Medicine, Isfahan University of Medical Sciences, Isfahan, Iran
}

\section{PROCENA ISTORIJE SKRININGA PAPA TESTA KOD PACIJENATA SA KARCINOMOM GRLIĆA MATERICE U PROVINCIJI ISFAHAN TOKOM 2014-2016 GODINE}

\author{
Mahmoud Mosayebi, Negah TavakoliFard \\ Institut za primarnu zdravstvenu zaštitu, Medicinski fakultet, Isfahan Univerzitet medicinskih nauka, Ishafan, Iran
}

\section{ABSTRACT}

Objective. The absence of regular screening of cervical cancer in Iran and high rate of diagnosed cancer in advanced stages show the importance of performing screening. Therefore, the aim of this study was to evaluate Pap smear screening history in patients with cervical cancer in Isfahan province during 2014-2016.

Methods. In this descriptive-analytical study, 77 patients with cervical cancer were selected in Isfahan province. Data were extracted from medical records. Kruskal-Wallis test, one-way analysis, Chi-Square and Mann-Whithney, T test and Pearson test were used for analysis of data.

Results. In current study, $38.9 \%$ of patients with cervical cancer did not perform Pap smear test during their lifetime. Moreover, $38.09 \%$ and $19.48 \%$ of patients performed screening less and more than 3 years before diagnosis, respectively. There was a significant relation between screening history and age at diagnosis, the number of pregnancies and age of the first sexual intercourse $(p<0.01)$. Statistical analysis showed that the level of education was higher in patients who were diagnosed less than 3 years than in those diagnosed more than 3 years $(p=0.04)$. The frequency of patients who performed screening in an urban area was significantly higher than a rural area $(p=0.048)$. Moreover, significant difference was observed between provider type screening service in terms of location ( $p=0.03)$.

Conclusion. The result of this study indicates the role of influential factors on Pap smear screening. Moreover, history of not performing Pap smear test in our country in comparison to other countries is high which leads to delayed diagnosis. Therefore, general screening program to improve awareness of population in this regard is necessary.

Key words: uterine cervical neoplasms; Papanicolaou test; mass screening.

\section{INTRODUCTION}

Cervical cancer is the most common neoplasm among women worldwide (1). It is estimated that 529,800 new cases worldwide are diagnosed with cervical cancer every year. The disease incidence is not common in the Western world (2). There are more than $85 \%$ of the cases in developing countries (3). It is estimated that the incidence

\section{SA ŽETAK}

Uvod. Odsustvo redovnog skrininga karcinoma grlića materice u Iranu $i$ visoke stope dijagnostikovanog karcinoma u uznapredovalim stadijumima pokazuju važnost izvođenja skrininga. Stoga je cilj ove studije bio da se proceni istorija skrininga Papa testa kod pacijenata sa karcinomom grlica materice u provinciji Isfahan tokom 2014-2016 godine.

Metode. U ovoj deskriptivno-analitičkoj studiji, 77 pacijenata sa karcinomom grlica materice je izabrano $u$ provinciji Isfahan. Podaci su izdvojeni iz medicinske dokumentacije. Za analizu podataka korišćeni su KruskalWallisov test, jednosmerna analiza, Chi-Square, MannWhithney, T test i Pearsonov test.

Rezultati. U trenutnoj studiji, 38,9\% pacijenata sa karcinomom grlića materice nije obavilo Papa test tokom svog života. Štaviše, $38.09 \%$ je obavilo skrining u period koji je kraći od 3 godine od postavljanja dijagnoze a $19.48 \%$ u period dužem od 3 godine. Postojala je značajna relacija između skrininga $i$ starosti pri dijagnozi, broja trudnoća $i$ starosti $u$ trenutku prvog seksualnog odnosa $(p<0,01)$. Statistička analiza je pokazala da je nivo obrazovanja bio veci kod pacijenata kod kojih je postavljena dijagnoza u period kraćem od 3 godine nego kod onih sa dijagnozom u period dužem od 3 godine $(p=0,04)$. Učestalost pacijenata koji su vršili skrining $u$ gradskoj zoni bila je značajno veća od ruralne $(p=0,048)$. Štaviše, uočena je značajna razlika između vrste provajdera usluga skrininga u smislu lokacije $(p=0,03)$.

Zaključak. Rezultat ove studije ukazuje na ulogu uticajnih faktora na Papa test skriningu. Štaviše, istorija nečinjenja Papa testa u našoj zemlji u odnosu na druge zemlje je visoka što dovodi do odložene dijagnoze. Stoga je neophodan opšti program skrininga za poboljšanje svesti stanovništva u tom pogledu.

Ključne reči: neoplazije grlića materice; Papanikolau test; masovni skrining.

rate of cervical cancer in Iran is 2.5 per 100,000 (4). According to a recent study, mortality rate of cervical cancer was $42 \%$ among these patients in Iran (4). If cervical cancer is detected in an early stage, it can be treated, while, advanced stage of cervical cancer is associated with poor prognosis and a lower survival rate (5-7). On the other hand, advanced cervical cancer is the main cause of mortality in women. Recently, early 
diagnosis is considered as the major issue in prevention and treatment of cancer. Therefore, the importance of cervical cancer screening for the early diagnosis of preinvasive lesions is highlighted.

Screening program supplies a low-cost way to decrease the rate of invasive cervical cancer (8). On the other hand, changing the incidence of cervical cancer demonstrated the impact of cervical cancer screening program (8). Moreover, screening program in many developed countries has been known as an effective and benefitial method (9). Pap smear is considered as the most effective screening tests for diagnosing of cervical illness (10). Pap smear screening has led to reduce the incidence and mortality of patients with cervical cancer (9). On the other hand, regular screening causes to treat and detect pre-invasive lesions before they become invasive (2). Moreover, women are faced with numerous cultural, emotional and practical obstacles to perform pop-smear (11).

Studies have shown that etiology of late diagnosis of cervical cancer can be benefitial in establishing comprehensive preventative strategies (12). It seems that factors including low awareness of screening, inadequate follow-up of abnormal Pap smears and inaccessibility routine screening can elucidate the reason of high mortality of cervical cancer. Although the cervical cancer incidence in Iran is low, the rate of mortality is relatively high and evaluation of Pap smear screening history in women with cervical cancer helps to obtain insights about this. Therefore, the aim of this study was to evaluate Pap smear screening history in patients with cervical cancer in Isfahan city during 2014-2016.

\section{MATERIALS AND METHODS}

This descriptive-analytical study was performed on all women with cervical cancer who were diagnosed by histopathological examination and confirmed in the national cancer registration unit during 2014-2016. This study was approved by ethics committee of Isfahan University of Medical Sciences with number 396290. Inclusion criteria were women with cervical cancer who are alive during the study. Moreover, the existence of documentation for performing Pap smears in patients is necessary. Exclusion criteria in these patients were lack of patient collaboration and patient death during the study. After evaluating the inclusion and exclusion criteria, 77 patients with cervical cancer were selected at this interval. Then, the data including age, smoking, diagnosis date, histopathology type, location, education, marital status, the age of the first sexual intercourse, screening history, screening interval, screening type, interval between time of diagnosis and the last Pap smear, the number of sex partners, symptoms and number of pregnancy and delivery were extracted from medical records of patients. Data were entered SPSS version 19. Kruskal-Wallis, one-way analysis of variance and anova test, Chi-Square test, Mann-Whithney test, T test and Pearson coefficient correlation were used for analysis of data.

\section{RESULTS}

In current study, 77 women with cervical cancer were selected. Furthermore, $84.3 \%$ and $15.7 \%$ of patients lived in urban and rural areas, respectively. In addition, 64 patients $(83.11 \%)$ were alive and $13(16.86 \%)$ died. In addition, $51.8 \%$ of patients we exposed to smoking. Quantitative variables of patients with cervical cancer are shown in Table 1.

The frequency of tumor histopathological type in patients with cervical cancer showed that Squamous Cell Carcinomas, adenocarcinoma and CINIII were observed in $51(66.2 \%), 7(9.09 \%)$ and 10 patients $(12.98 \%)$, respectively. The rest were diagnosed with other histopathological type. The frequency of symptoms including vaginal discharge, vaginal bleeding, intermenstrual bleeding, Postmenopausal bleeding, bleeding after intercourse, sever (abnormal) bleeding, reduced appetite, pain and fatigue were shown in Table 3.

As shown in Table 3, vaginal bleeding (57.1\%) and severe bleeding $(45.5 \%)$ were the most frequent symptoms in cervical cancer patients. Moreover, reduced appetite was the least frequent symptom (6.5\%). The history of performing screening for cervical cancer showed that among all patients with cervical cancer, 30 patients $(38.96 \%)$ had never performed Pap smear test.

Table 1. Quantitative variable in patients with cervical cancer

\begin{tabular}{|l|c|c|c|}
\hline Variable & Mean \pm SD & Minimum & Maximum \\
\hline Age at diagnosis time (years) & $52.3 \pm 14.2$ & 27 & 85 \\
\hline Number of pregnancies & $4.04 \pm 2.7$ & 0 & 13 \\
\hline Number of deliveries & $3.6 \pm 2.5$ & 0 & 10 \\
\hline Age of the first sexual intercourse & $17.7 \pm 5.8$ & 9 & 39 \\
\hline Number of screenings & $1.02 \pm 1.6$ & 0 & 7 \\
\hline $\begin{array}{l}\text { The interval for the last Pap smear and } \\
\text { time of diagnosis (year) }\end{array}$ & $1.2 \pm 0.5$ & 1 & 3 \\
\hline
\end{tabular}


Table 2: Qualitative variable in patients with cervical cancer

\begin{tabular}{|l|c|c|}
\hline Variable & Number & Percent \\
\hline The level of education & & \\
Primary level & 40 & 51.9 \\
Medium level & 26 & 33.8 \\
Academic level & 11 & 14.3 \\
\hline Number of sex partners & & \\
One person & 70 & 90.9 \\
More than one person & 2 & 2.59 \\
Unknown & 5 & 6.51 \\
\hline
\end{tabular}

Table 3. Frequency of symptoms in patients with cervical cancer

\begin{tabular}{|l|c|c|}
\hline Symptoms & Number & Percent \\
\hline Vaginal discharge & 33 & 42.90 \\
\hline Vaginal bleeding & 44 & 57.10 \\
\hline Intermenstrual bleeding & 23 & 29.90 \\
\hline Postmenopausal bleeding & 22 & 28.60 \\
\hline Bleeding after intercourse & 28 & 36.40 \\
\hline Sever(abnormal) bleeding & 35 & 45.50 \\
\hline Non-specific bleeding & 26 & 33.80 \\
\hline Reduced appetite & 5 & 6.50 \\
\hline Pain & 21 & 27.30 \\
\hline Fatigue & 12 & 15.60 \\
\hline
\end{tabular}

Moreover, 30 (38.96\%) and $15(19.48 \%)$ performed screening pap-smear test less than and more than 3 years before diagnosis. In addition, 2 cases were missed. The level of education was higher in patients who were diagnosed less than 3 years than those more than 3 years $(p=0.04)$. Moreover, no significant difference was observed between education in terms of compliance with the national guidelines $(p=0.48)$ and provider type screening service $(p=0.17)$. Table 4 shows correlation between variables (age at diagnosis time, number of pregnancies, age of the first sexual intercourse and education) with the number of screenings and the interval for the last Pap smear and time of diagnosis.

As shown in Table 4, inverse correlation was observed between the number of pregnancies and the number of screening times $(\mathrm{p}<0.05)$. Moreover, significant correlation was observed between the number of pregnancies with the interval for the last Pap smear and the time of diagnosis $(p<0.05)$. The relation between screening history with the age at diagnosis time, number of pregnancies and age of the first sexual intercourse is shown in Table 5.

There was a significant relation between screening history and the age at diagnosis time, number of pregnancies and age of the first sexual intercourse $(p<0.01)$. Table 6 shows the difference between variables including history of screening for cervical cancer, compliance with the national guidelines and provider type screening service in terms of location.

As it is clear from Table 6, the frequency of patients who did not have screening in rural areas was significantly

Table 4. Correlation between variables with the number of screening times and the interval for the last Pap smear and time of diagnosis

\begin{tabular}{|l|c|c|c|c|}
\hline \multirow{2}{*}{ Variable } & \multicolumn{2}{|c|}{$\begin{array}{c}\text { The number of screening } \\
\text { times }\end{array}$} & \multicolumn{2}{c|}{$\begin{array}{c}\text { The interval for the last Pap smear and } \\
\text { time of diagnosis (year) }\end{array}$} \\
\cline { 2 - 5 } & $\mathrm{r}$ & $\mathrm{p}$ & $\mathrm{r}$ & $\mathrm{p}$ \\
\hline Age at diagnosis time & -0.2 & 0.18 & 0.11 & 0.44 \\
\hline The number of pregnancies & -0.29 & 0.04 & 0.304 & 0.03 \\
\hline $\begin{array}{l}\text { Age of the first sexual } \\
\text { intercourse }\end{array}$ & 0.14 & 0.4 & -0.123 & 0.43 \\
\hline Education & 0.02 & 0.9 & 0.069 & 0.69 \\
\hline
\end{tabular}

Table 5.

\begin{tabular}{|l|c|c|c|c|}
\hline Screening history variable & Never & Less than 3 years & More than 3 years & $\mathrm{P}^{*}$ \\
\hline Age at diagnosis time & $61.2 \pm 15.4$ & $45.4 \pm 10.6$ & $48.9 \pm 8.4$ & $<0.001$ \\
\hline Number of pregnancies & $5.2 \pm 3.2$ & $2.9 \pm 1.7$ & $4.3 \pm 2.3$ & 0.004 \\
\hline Age of the first sexual intercourse & $15.4 \pm 5.5$ & $19.8 \pm 6.1$ & $16.8 \pm 3.7$ & 0.002 \\
\hline
\end{tabular}

*One-way anova test 
Table 6. Difference between variables (history of screening for cervical cancer, compliance with the national guidelines and type of service) in terms of location

\begin{tabular}{|l|l|c|c|l|}
\hline Variables & Time & Rural & Urban & P* \\
\hline \multirow{3}{*}{ History of screening for cervical cancer } & Never & $8(50 \%)$ & $21(35.6 \%)$ & \multirow{2}{*}{0.046} \\
\cline { 2 - 4 } & Less than 3 years & $3(18.8 \%)$ & $28(47.5 \%)$ & \\
\cline { 2 - 4 } & More than 3 years & $5(31.2 \%)$ & $10(16.9 \%)$ & \\
\hline \multirow{2}{*}{ Compliance with the national guidelines } & Yes & $4(50 \%)$ & $20(52.6 \%)$ & \multirow{2}{*}{0.6} \\
\cline { 2 - 4 } & No & $4(50 \%)$ & $18(47.4 \%)$ & \\
\hline Provider type screening service & Governmental & $6(75 \%)$ & $12(31.6 \%)$ & \multirow{2}{*}{0.03} \\
\cline { 2 - 4 } & Private & $2(25 \%)$ & $26(68.4 \%)$ & \\
\hline
\end{tabular}

\section{*Chi Square test}

higher than in urban areas $(\mathrm{p}<0.05)$. Moreover, a significant difference was observed between provider type screening service in terms of location $(p<0.05)$. The frequency of screening in rural and urban area was $0.9 \pm 1.4$ and $1.1 \pm 1.7$, respectively $(\mathrm{p}=0.71)$. The interval for the last Pap smear and the time of diagnosis in rural and urban area was $1 \pm 0$ and $1.3 \pm 0.5$, respectively. There was no significant difference between the interval for the last Papsmear and the time of diagnosis in terms of location $(p=0.10)$.In addition, no significant difference was observed between the mean age of patients $(p=0.53)$, the number of pregnancies $(p=0.73)$ and the age of the first sexual intercourse $(p=0.48)$ in terms of compliance with the national guidelines. In addition, there was no significant differences between the mean age of patients $(p=0.31)$, the number of pregnancies $(p=0.66)$ and the age of the first sexual intercourse $(p=0.49)$ in terms of type of service provider.

\section{DISCUSSION}

In current study, about $39 \%$ of patients with cervical cancer did not perform Pap smear test during their lifetime. Subramaniam et al., in a study in Birmingham during 2011 reported that $1 \%$ of patients had never performed Pap smear test (13). Spence et al., in their study reported that $85 \%-90 \%$ of women had undergone a Pap smear test at least once in their lifetime. This indicates a history of not performing Pap smear test in our country is high which leads to delayed diagnosis (2). Moreover, there was a significant relation between screening times and the age of diagnosis time. So that higher age at diagnosis time was observed in those who had never performed screening during their life. It showed that screening causes that patients were diagnosed earlier during their life. Darlin et al., reported that diagnosis of cervical cancer in women above 65 years is associated with advanced stages of the disease and poor prognosis (14).

Moreover, in our study, the number of patients who underwent Pap smear less than 3 years ago was about 2 times higher than those who underwent Pap smear more than 3 years before diagnosis. Furthermore, our results showed that patients who underwent Pap smear less than 3 years had less deliveries, higher age of the first sexual intercourse and lower age at diagnosis time in comparison to those who underwent Pap smear more than 3 years ago. Spence et al., confirmed our study and reported that cancer risk was higher in patients who performed screening more than 3 years before diagnosis (2). Subramaniam et al., reported that $20 \%$ of patients performed Pap smear test in the last 2 years and advanced stages of cervical cancer were uncommon among them (13).

In current study, the evaluation of effective parameters on Pap smear test showed that a significant relation was observed between education level and early diagnosis (less than 3 years compared to more than 3 years). Behnamfar et al., in their study evaluated factors associated with delayed diagnosis in patients with cervical cancer. Their results showed that lower level of education, smoking, economic status causes delayed diagnosis of cervical cancer (1). Ma et al. showed that factors including older age, lower education, low income and being widow/divorced were considered as the high-risk factors for delayed detection of cervical cancer (15). Behnamfar et al., reported that no significant associations were observed between place of residence and delayed diagnosis of cervical cancer which is inconsistent with our study. It is noticed that Behnamfar study in comparison with our study was conducted in a smaller community. Moreover, in current study, inverse correlation was observed between the number of pregnancies and the number of screenings. Perhaps more children cause that mothers have less time to perform self-examination and screening tests.

The association between smoking and cervical cancer has been reported in many studies. In our study, $51.8 \%$ of patients were exposed to smoking. Louie et al evaluated the factors influencing cervical cancer and reported that smoking can affect cervical cancer. Although the 
mechanism how smoking induce cervical cancer is not known clearly, tobacco smoke contains a carcinogen component which leads to immunosuppression and consequently progression of HPV infection to cancer (16, 17). Considering the increased rate of smoking in developing countries and increasing trend of smoking in young females, effective tobacco control programs should be performed to prevent cervical cancer (18).

In current study, most of cervical cancer patients had Squamous Cell Carcinomas (66.2\%) and adenocarcinoma (7\%). Subramaniam et al., in accordance with our study reported that the the most common histologic type of cervical cancer was squamous cell carcinoma and adenocarcinom, respectively (13). In addition, vaginal bleeding was the most common symptom in patients with cervical cancer in our study. Eleje et al., reported that women in advanced stage of cervical cancer usually suffer from vaginal bleeding. Moreover, bleeding is considered as the immediate cause of death in $6 \%$ of women and vaginal bleeding management is often associated with challenges, particularly in developing countries, because access to radiotherapy is limited (19). Chen et al., reported that vaginal bleeding is a life treating in advanced stages and endovascular therapy should be done in patients with advanced cervical cancer for the control of active vaginal bleeding (20).

Place of living is another factor that affect Pap smear, so that significant difference was observed between rural and urban area in terms of cervical cancer screening. Moreover, there was a significant difference between provider type screening service in rural and urban areas. Women in rural and urban areas tend to use governmental and private service providers, respectively. Our study was consistent with Orwat et al., study. They demonstrated that notable difference was observed between cervical cancer screening rate among women in rural and urban areas (21). They also reported that there is a need to increase the use of screening services and decrease barriers to services in rural areas. Horner-Johnson et al., in another study reported that women in rural areas received less cervical cancer screening (22). Bishwajit et al., performed one study in Kenya and reported that identification of regional barriers for preventing rural women from using the screening services is necessary (23). Therefore, it seems that increased attention is required to improve receipt of cancer screening among rural women with disabilities.

In conclusion, the result of this study indicates the role of influential factors on Pap smear screening. Moreover, history of not performing Pap smear test in our country in comparison to other countries is high. Therefore, general screening program to improve awareness of population in this regard is necessary. It is proposed that this study is considered with larger sample size and a case control group in future.

\section{CONFLICT OF INTEREST}

There is no conflict of interest.

\section{REFERENCES}

1. Behnamfar F, Azadehrah M. Factors associated with delayed diagnosis of cervical cancer in Iran - a survey in Isfahan City. Asian Pac J Cancer Prev 2015; 16:635-9.

2. Spence AR, Alobaid A, Drouin P, et al. Screening histories and contact with physicians as determinants of cervical cancer risk in Montreal, Quebec. Curr Oncol 2014; 21:294-304.

3. Jemal A, Bray F, Center MM, Ferlay J, Ward E, Forman D. Global cancer statistics. CA Cancer J Clin 2011; 61:69-90.

4. Khorasanizadeh F, Hassanloo J, Khaksar N, et al. Epidemiology of cervical cancer and human papilloma virus infection among Iranian women - analyses of national data and systematic review of the literature. Gynecol Oncol 2013; 128:277-81.

5. Devi BC, Tang TS, Corbex M. Reducing by half the percentage of late-stage presentation for breast and cervix cancer over 4 years: a pilot study of clinical downstaging in Sarawak, Malaysia. Ann Oncol 2007; 18:1172-6.

6. Vinh-Hung V, Bourgain C, Vlastos G, et al. Prognostic value of histopathology and trends in cervical cancer: a SEER population study. BMC Cancer 2007; 7:164.

7. Thomson CS, Forman D. Cancer survival in England and the influence of early diagnosis: what can we learn from recent EUROCARE results? Br J Cancer 2009; 101:102-9.

8. Nygård JF, Skare GB, Thoresen SØ. The cervical cancer screening programme in Norway, 1992-2000: changes in Pap smear coverage and incidence of cervical cancer. J Med Screen 2002; 9:86-91.

9. Othman NH, Devi BC, Halimah Y. Cervical cancer screening: patients understanding in major hospitals in Malaysia. Asian Pacific J Cancer Prev 2009; 10:56974.

10. Shy K, Chu J, Mandelson M, Greer B, Figge D. Papanicolaou smear screening interval and risk of cervical cancer. Obstet Gynecol 1989; 74:838-43.

11. Massomi Z, Khani S, Gharosian M, Farhadian M, Shayan A. The prevalence of abnormal Pap smears in females referred to health centers affiliated to medical sciences during the Years 2012 to 2016. J Educ Community Health 2016; 3:16-22.

12. Allgar VL, Neal RD. Delays in the diagnosis of six cancers: analysis of data from the National Survey of NHS Patients: Cancer. Br J Cancer 2005; 92:1959-70. 
13. Subramaniam A, Fauci JM, Schneider KE, et al. Invasive Cervical Cancer and screening: what are the rates of unscreened and underscreened women in the modern era? J Low Genit Tract Dis 2011; 15:110-3.

14. Darlin L, Borgfeldt C, Widén E, Kannisto P. Elderly women above screening age diagnosed with cervical cancer have a worse prognosis. Anticancer Res 2014; 34:5147-51.

15. Ma J, Zhu Q, Han S, et al. Effect of socio-economic factors on delayed access to health care among Chinese cervical cancer patients with late rectal complications after radiotherapy. Gynecol Oncol 2012; 124:395-8.

16. WHO International Agency for Research on Cancer (IARC). Tobacco smoke and involuntary smoking. Lyon, France, 2004.

17. Louie KS, Castellsague X, de Sanjose S, et al (2011); International agency for research on cancer multicenter cervical cancer study group. Smoking and passive smoking in cervical cancer risk: pooled analysis of couples from the IARC multicentric casecontrol studies. Cancer Epidemiol Biomarkers Prev 2011; 20:1379-90.
18. Samet JM, Yoon S-Y. Gender, women, and the tobacco epidemic. Geneva, Switzerland: World Health Organization, 2010.

19. Eleje GU, Eke AC, Igberase GO, Igwegbe AO, Eleje LI. Palliative interventions for controlling vaginal bleeding in advanced cervical cancer. Cochran Collaboration: John Wiley \& Sons, Ltd, 2016.

20. Chen CS, Park S, Shin JH, et al. Endovascular treatment for the control of active vaginal bleeding from uterine cervical cancer treated with radiotherapy. Acta Radiol 2018; 59:1336-42.

21. Orwat J, Caputo N, Key W, De Sa J. Comparing rural and urban cervical and breast cancer screening rates in a privately insured population. Soc Work Public Health 2017; 32:311-23.

22. Horner-Johnson W, Dobbertin K, Jezzoni LI. Disparities in receipt of breast and cervical cancer screening for rural women age 18 to 64 with disabilities. Womens Health Issues 2015; 25:246-53.

23. Bishwajit G, Kpoghomou MA. Urban-rural differentials in the uptake of mammography and cervical cancer screening in Kenya. J Cancer Policy $2017 ; 12: 43-8$. 